\title{
Study of two pharmaceutically useful Psoralea (Leguminosae) species : influence of inoculation on growth, grain and dry matter yield
}

\author{
F Bourgaud 1, N Allard 1, P Forlot 2, A Guckert 1* \\ 1 INRA-Phytotechnie, ENSAIA, 2, avenue de la forêt de Haye, 54500 Vandœuvre-lès-Nancy; \\ 2 Laboratoires Pharmaceutiques Bergaderm SA, 46, rue de la Grosse Pierre, Silic 189, \\ 94563 Rungis Cedex, France
}

(Received 6 March 1989; accepted 8 November 1989)

\begin{abstract}
Summary - The germination, vegetative growth, grain yield and dry weight yield were studied in 2 Australian medicinal plants of the genus Psoralea: Psoralea cinerea and Psoralea plumosa. The germination method was shown to be very efficient (germination rate about $90 \%$ ). The plants were then grown under phytotronic conditions, testing nitrogen fertilization compared to inoculation with 3 different Bradyrhizobium strains (CB 2063, USDA 3451, USDA 3100 ). The best grain yields were obtained with strain CB 2063 for $P$ cinerea and with the 2 strains CB 2063 and USDA 3451 for $P$ plumosa. These plants bore abundant fruits and the seeds obtained were able to germinate normally. The growth conditions applied here are thus suited to the 2 species, which will be studied further in a more extensive crop trial (greenhouse or field).
\end{abstract}

\section{Psoralea cinerea / Psoralea plumosa / Bradyrhizobium / germination / vegetative growth / yield / furocoumarin}

Résumé - Étude de deux espèces de Psoralées (légumineuses) à intérêt pharmaceutique: influence de l'inoculation sur la croissance et les rendements en grain et matière sèche. Nous avons étudié le cycle de développement, depuis la germination jusqu'à la récolte des semences, de deux espèces de Psoralées australiennes à intérêt pharmaceutique : Psoralea cinerea et Psoralea plumosa. Les semences présentent une double inhibition de germination. La première est d'ordre mécanique (épaisseur du tégument), la seconde a une origine chimique (psoralène contenu dans la semence). Le protocole de germination proposé consiste en un trempage des semences dans de l'eau chaude à $60^{\circ} \mathrm{C}$ durant $4 \mathrm{~h}$ suivi d'une scarification manuelle. II s'avère très efficace (taux de germination de l'ordre de 90\%). Les plantes ont ensuite été conduites en conditions contrôlées (phytotron) en testant l'effet d'une fertilisation azotée et de l'inoculation de 3 souches de Bradyrhizobium étudiées séparément (CB 2063, USDA 3451, USDA 3100). Nous avons suivi le développement de ces plantes par des mesures de hauteur et du nombre de feuilles pendant la période de végétation (figs 1,2, 3 et 4). Les meilleurs résultats de croissance et de rendement en grain ont été obtenus avec la souche CB 2063 pour P cinerea (fig 5 et tableau I) et avec les 2 souches CB 2063 et USDA 3451 pour P plumosa (fig 6 et tableau II). Les plantes des traitements correspondants ont fructifié abondamment et les semences récoltées sont aptes à germer normalement. Les conditions de végétation appliquées conviennent donc parfaitement aux 2 espèces étudiées qui se prêteront à l'avenir à un essai de culture sur de plus grandes surfaces (serre ou plein champ).

Psoralea cinerea / Psoralea plumosa / furocoumarines / Bradyrhizobium / germination / croissance végétative / rendement

\section{INTRODUCTION}

The genus Psoralea (Leguminosae) is rare in Europe, with a single species in the mediterranean area ( $P$ bituminosa), but is well represented in the arid zones of South Africa, North America and Australia (Allen and Allen,
1981). Apart from their value in pasture improvement in hot regions (Dorbec, 1985), these plants are of some interest to the pharmaceutical industry since they produce active substances (furocoumarins) used in cosmetic products, and increasingly, in dermatology.

\footnotetext{
* Correspondence and reprints
} 
At present, these compounds are essentially obtained from bergamot oil (Bourgaud et al, 1989) since their chemical synthesis is prohibitively expensive. However, in view of the low levels of bergamot (Citrus bergamia), production it is advisable to turn to other richer plant resources to meet the increasing requirements of the pharmaceutical industry.

A recent publication (Innocenti et al, 1984) has shown the value of Australian species of Psoralea which synthesize appreciable contents of furocoumarins in the seeds (depending on the species, the seeds contain $1000-8000 \mathrm{ppm}$ total furocoumarins per $\mathrm{g}$ dry weight). This finding led us to turn our attention to this group of plants and notably to two species, $P$ cinerea and $P$ plumosa (being the richest in furocoumarins among those analysed by Innocenti et al, 1984) with a view to subsequent cultivation in greenhouses or in the field. Since nothing is known about furocoumarins concentration in the other parts of the plants (especially vegetative organs), we decided to study the whole plants in order to determine later the most interesting tissues for production of furocoumarins.

These are two species originating from the semi-arid regions of Western Australia $(350 \mathrm{~mm}$ annual rainfall, mean maximum temperature $35^{\circ} \mathrm{C}$, mean minimum temperature $11^{\circ} \mathrm{C}$ ) and growing best in sandy soils (Beadle, 1964; Torrey and Gray, 1969, Keighery and Dixon, 1981). Since they are legumes they establish symbiosis with Rhizobium of the "cowpea" type (slow growing Rhizobium, now classed as Bradyrhizobium) and thus contribute to enriching the soils on which they grow (Beadle, 1964). However, there have been few studies of nodulation and crossed inoculation experiments in Psoralea species (Appleman and Sears, 1942), nor is there any available information on the growing cycle of these plants. These plants also present problems in germination due to the occurrence of a double inhibition (Baskin et al, 1967): mechanical inhibition: the seeds possess a very thick tegument preventing their rehydratation; chemical inhibition: the pericarp contains a substance that inhibits germination. This substance is a furocoumarin (psoralen) which is 1 of the medically interesting metabolites.

In this initial study, we first sought to determine the appropriate technique for germination of the 2 plants. We then studied the vegetative growth cycle under controlled conditions, with particular emphasis on the flowering-maturation phase. With a view to later utilisation and improvement, the major objective was to understand the factors involved in determining grain yield. The third stage was to determine the growth conditions giving optimal biomass and grain yields. To this end, we considered it essential to test the importance of the Psoralea-cowpea Rhizobium symbiosis to the growth of these two chosen species, using different bacterial strains. Nitrogen fertilization and cowpea Rhizobium inoculation were thus compared in order to develop a cultivation method adapted to good vegetative growth and allowing the production of effective biomass and grain yield.

\section{MATERIALS AND METHODS}

\section{Germination test}

The seeds ( $P$ cinerea, $P$ plumosa), supplied by the Perth botanical gardens, were placed in warm water $\left(60^{\circ} \mathrm{C}\right)$ for $4 \mathrm{~h}$ and their tegument was then nicked, taking care not to injure the cotyledons (the seeds are exalbuminous). The seeds treated in this way were placed in moist filter at $25^{\circ} \mathrm{C}$ in the dark.

\section{Experimental methods}

\section{Cultivation of the plants}

After germination, the seedlings were transferred to vermiculite moistened with the nutrient medium described by Wood et al (1983) until the 2-leaf stage. They were then replanted into individual pots $(10 \times 10 \times 11 \mathrm{~cm})$ containing $130 \mathrm{~g}$ of a sand-gravel mixture in the bottom and $600 \mathrm{~g}$ sandy earth on top. The pots were placed in a growth chamber under the following conditions: $15 \mathrm{~h}$ of illumination at $25^{\circ} \mathrm{C}, 9 \mathrm{~h}$ of darkness at $18{ }^{\circ} \mathrm{C}, 70 \% \mathrm{r}$. The illumination was approximately $600 \mu \mathrm{E} \mathrm{m}^{-2} \mathrm{~s}^{-1}$. The soil was kept at $2 / 3$ of the water holding capacity.

\section{Selection and cultivation of Rhizobium}

Among the Rhizobium cultures available to us we chose 3 strains for their ability to induce nodulation of Psoralea plants: CB 2063 isolated from Psoralea cinerea in Australia (Brockwell, personal communication);

USDA 3 100: isolated from Psoralea psoraloides in the USA (Keyser and Griffin, 1987);

USDA 3 451: isolated from Macrotyloma africanum in Africa. This strain is known to be able to nodulate a large number of tropical leguminous species (Keyser and Griffin, 1987).

The selected strains were cultivated in liquid yeast extract-mannitol broth medium $(0.4 \mathrm{~g} / \mathrm{l})$ (Vincent, 1970) and were inoculated at a rate of $10^{\circ}$ bacteria per plant. The roots were examined at the end of the experiment to determine the presence or absence of nodules.

\section{Experimental design}

Five treatments, each in 10 replicates, were applied to each of the 2 studied species: 1) control: plants 
without fertilizer and not inoculated; 2) nitrogen: plants fertilized with ammonium nitrate at a rate of 50 units of nitrogen per ha; 3) CB 2 063: plants inoculated with bacteria of strain CB 2063 ; 4) USDA 3 451: plants inoculated with bacteria of strain USDA 3451 ; 5) USDA 3 100: plants inoculated with bacteria of strain USDA 3100.

The relatively low nitrogen dose of 50 units $\cdot \mathrm{ha}^{-1}$ was adopted since Psoralea species grow on poor soils. Knowing that the first nodules have been observed at the 3-4 leaf stage in the plants of the same genus (Beadle, 1964), the bacterial inoculum and nitrogen application were given at the 4-leaf stage.

\section{Growth monitoring-Estimation of yield}

\section{Growth monitoring}

Biometric measurements were undertaken twice weekly: plant height from the stem base to the terminal bud; total number of leaves per plant. The emergence of flower buds, the start of flowering and the maturation stage were also noted for each species and each treatment.

\section{Estimation of yield}

The seeds harvested as they matured were placed in an incubator at $25^{\circ} \mathrm{C}$ (a temperature not affecting the germinating potential of the seeds so that they could be utilized later) for 2 weeks in order to obtain homogeneous moisture contents. At the end of the experiment the different plant organs were separated (roots, stems, leaves, immature fruits) and dried in an oven at $35^{\circ} \mathrm{C}$ for 2 weeks to obtain the dry material yield of these organs per species and per treatment (this relatively low temperature does not affect any furocoumarins that may be present so that they can be assayed in a future study).

Concerning yield parameters, we used the following formulation:

yield/plant $=$ (number of inflorescences/plant) $\times$ (number of fruits/inflorescence) $\times$ (number of seeds/fruit) $x$ (1 000 seed weight) / 1000

As there is always only 1 seed per fruit, we obtain: (number of fruits/inflorescence) = number of seeds/ inflorescence. The parameters: yield/plant, number of inflorescence per plant, 1000 seed weight were measured at the end of the vegetation period. The number of seeds/inflorescence was not measured but calculated.

\section{Statistical analysis}

The twice weekly biometric data were interpreted by analysis of variance and the Newman-Keuls test for comparison of means in order to notice if there were significant differences due to inoculation/fertilization between the treatments.

During harvest, we determined standard deviation for seed, leaf, stem and root weight within each treatment, but not for immature fruits.

\section{RESULTS}

The observations were made over a period of $130 \mathrm{~d}$ in the case of $P$ cinerea (equivalent to 2900 degree-days when summing the positive temperatures) and $140 \mathrm{~d}$ in the case of $P$ plumosa (corresponding to 3090 degreedays). The results for germination method are presented first, followed by those relating to the growth of aerial and reproductive organs, with particular attention paid to the role of inoculation.

\section{Germination}

Using the method described above, applied to batches of 50 seeds per species, germination rates of $90 \%$ were obtained with $P$ cinerea and $96 \%$ with $P$ plumosa after $48 \mathrm{~h}$ in an incubator. The only seeds which did not germinate showed cotyledons or embryos damaged by insect attack. In parallel with this, the possibility of germinating seed batches of both species without warm water treatment or scarification was tested. The filter paper then showed brown haloes around the seeds, effectively demonstrating the diffusion of a water-soluble compound that is probably psoralen (Baskin et al, 1967). However, no germination was found after $15 \mathrm{~d}$. These 2 batches of 20 seeds were then scarified by hand and germination occurred within $24 \mathrm{~h}(95 \%)$.

The method proposed by Baskin et al (1967) thus proved to be very efficient with both tested Psoralea species and the need for 2 interventions: steeping in warm water and scarification, can be confirmed.

As a complement to these observations, the possible existence of dormancy other than the said chemical and mechanical dormancy was examined (comparable to the thermodependent physiological dormancy of wheat, for example). The seeds collected after the first vegetative season of our plants were used for this purpose. Fifty seeds per species were subjected to the germination procedure less than 1 month after harvesting and, after warm water treatment and scarification, a germination rate of $95 \%$ was recorded. Consequently, the seeds obtained under our conditions are able to germinate and there seems to be no other type of inhibition of germination (physiological dormancy).

\section{Vegetative growth}

\section{Height}

Under our conditions the plants reached a maximal height of about $60 \mathrm{~cm}$ after $130 \mathrm{~d}$ of 
growth in the case of $P$ cinerea (fig 1) and $30 \mathrm{~cm}$ after $140 \mathrm{~d}$ in the case of $P$ plumosa (fig 2). The effect of the fertilization-inoculation factor on the height of the 2 species was significant from the 5 th day after the treatment until the end of the experiment. In $P$ cinerea, the best results for growth in height were obtained with strain CB 2063 from the 19th day. In contrast, in $P$ plumosa these strains induced only a moderate growth curve (same results with strain USDA 3 451) ending in a plateau corresponding to the reproductive period of this species. $P$ plumosa inoculated with these 2 strains developed a lot of reproductive organs which, on the other hand, induced slow growth in height compared with control. Plants inoculated with strain USDA 3100 showed a curve comparable to that of the controls.

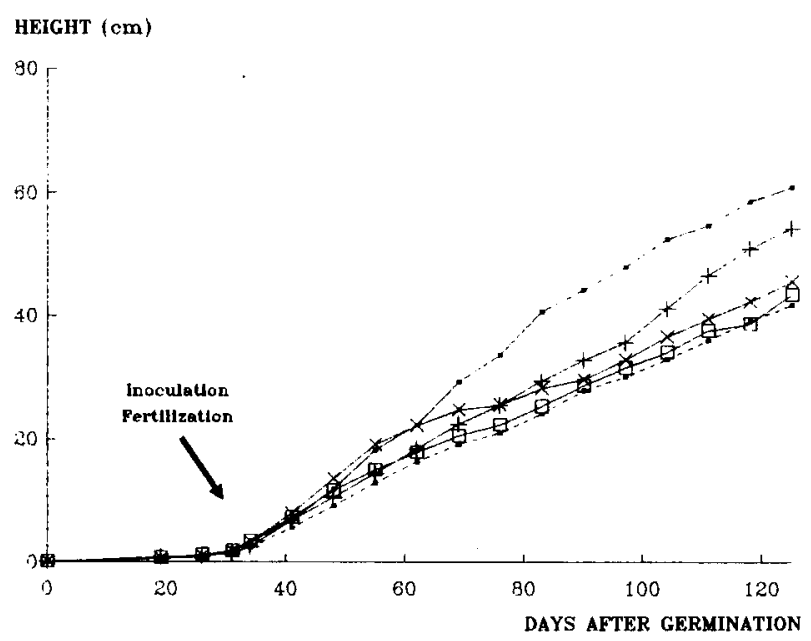

Fig. 1. Effects of treatments (bacterial inoculations or nitrogen fertilization) on growth in height $(\mathrm{cm})$ of Psoralea cinerea during the days after germination. - - CB $2083 ;-1$ USDA 3451 ; - - control; $\square$ USDA $3100 ; \rightarrow$ nitrogen.

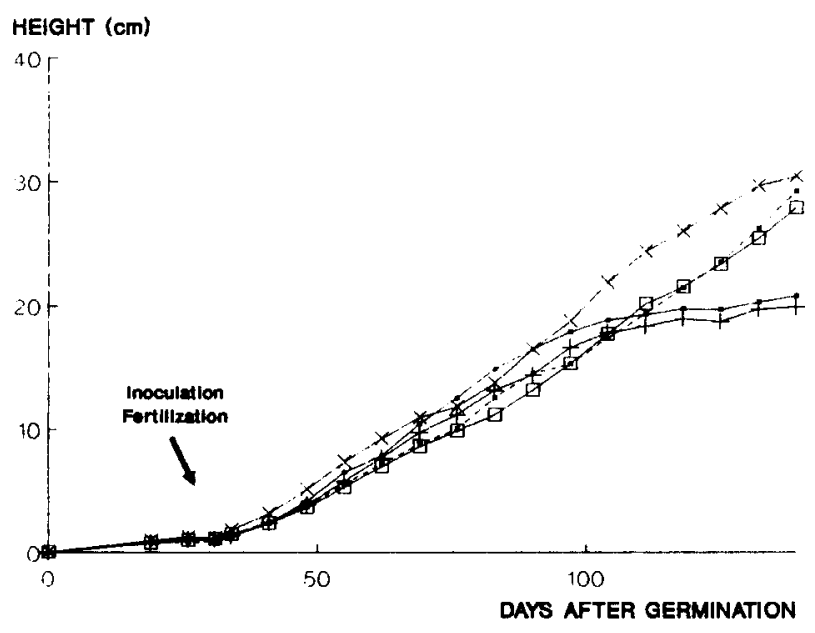

Fig. 2. Effects of treatments (bacterial inoculations or nitrogen fertilization) on growth in height $(\mathrm{cm})$ of Psoralea plumosa during the days after germination. $\rightarrow-$ CB $2083 ;+$ USDA 3451 ; - - - control; - $\square$ USDA $3100 ;-*$ nitrogen.

\section{Total number of leaves}

Both species have trefoil leaves, the number of which reaches about 20 for $P$ cinerea and over 25 in the case of $P$ plumosa. One leaf needs $6 \mathrm{~d}$ to develop completely for $P$ cinerea (134 degreedays) and $7 \mathrm{~d}$ in case of $P$ plumosa (157 degreedays). The effect of fertilization-inoculation was significant from the 23rd day for $P$ cinerea but only from the 45 th day for $P$ plumosa. In $P$ cinerea (fig 3), only treatment with CB 2063 led to a large number of leaves (the 2 decreases observed were due to accidental drying). In $P$ plumosa (fig 4) the 2 treatments with $\mathrm{CB} 2063$ and USDA 3451 led to a large number of leaves, whereas the plants fertilized with nitrogen had only an average number of leaves. The controls and plants treated with USDA 3100 showed a constant number of leaves since the plants shed

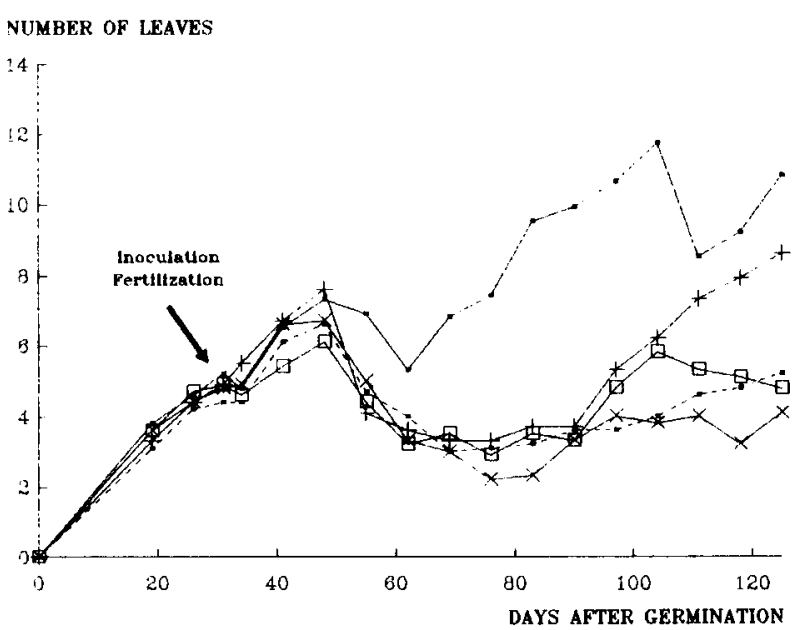

Fig. 3. Effects of treatments (bacterial inoculations or nitrogen fertilization) on total number of leaves of Psoralea cinerea during the days after germination. - CB $2083 ;+$ USDA 3451 ; - - control; $\square-$ USDA $3100 ; *-$ nitrogen.

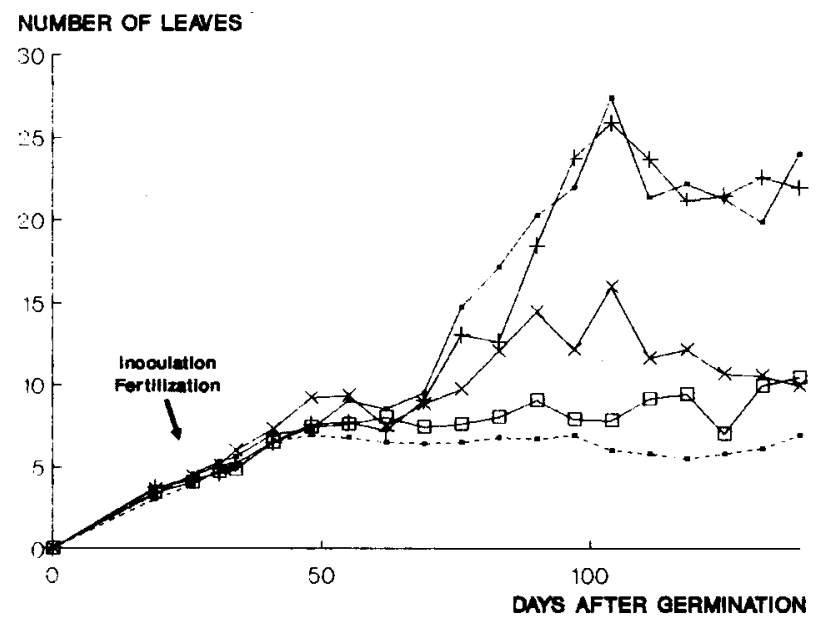

Fig. 4. Effects of treatments (bacterial inoculations or nitrogen fertilization) on total number of leaves of Psoralea plumosa during the days after germination. $\rightarrow-$ CB $2083 ;+$ USDA 3451 ; - - control; $\rightarrow$ - USDA $3100 ; \rightarrow-$ nitrogen. 
their old leaves as they were replaced by new. In the case of $P$ cinerea treated with USDA 3451 , an increase in the total number of leaves was observed from the 90th day.

\section{Flowering}

The flower buds in both species appear on long floral peduncles in the leaf axils from the 6th or 7th leaf. The inflorescences are spikes in which the lateral buds each give rise to 3 flowers. There are 10-30 flowers per inflorescence in $P$ cinerea and $10-15$ in $P$ plumosa.

The flower buds appeared around the 40th day after germination with all treatments of $P$ cinerea (about 900 degree-days) and around the 60th day (about 1340 degree-days) with all treatments of $P$ plumosa. Flowering was basifugal along the stem, with staging of maturation from the base to the apex of each plant. In both species, the flowering-fruiting period lasted for a period of $\approx 2.5$ months, a flower remained $15 \mathrm{~d}$ (335 degree-days) on the plant, and the maturation lasted $20 \mathrm{~d}$ (450 degree-days). Since the plants had been kept within a phytotron throughout their growth cycle, fruiting must have resulted from self-pollination of the flowers.

\section{Grain and dry matter yields}

\section{Dry matter yield}

In addition to the biomasses of the leaves, stems and roots, interest also centered in the number of immature fruits since they are often the parts richest in furocoumarins (Innocenti, personal communication). The results were very clear for $P$ cinerea (fig 5). The best yields were obtained with strain CB 2063 , closely followed by USDA 3451 treatment. With all treatments the leaf biomass was equal to that of the roots, whereas the stems amounted to at least twice the leaf biomass. The importance of the stems and the low leaf biomass are related to the erect habit of this plant.

The results were less clear with $P$ plumosa (fig 6). Ignoring the values relative to the roots, the greatest aerial biomasses (leaves plus stems) were obtained with strain USDA 3451 in relation to the leaves and immature fruits, and with nitrogen in relation to stems. However, the aerial biomass remained low $(5 \mathrm{~g} / 10$ plants for stems with nitrogen treatment) compared with that observed with $P$ cinerea (over $10 \mathrm{~g} / 10$ plants for stems with $\mathrm{CB} 2063$ treatment). $P$ plumosa

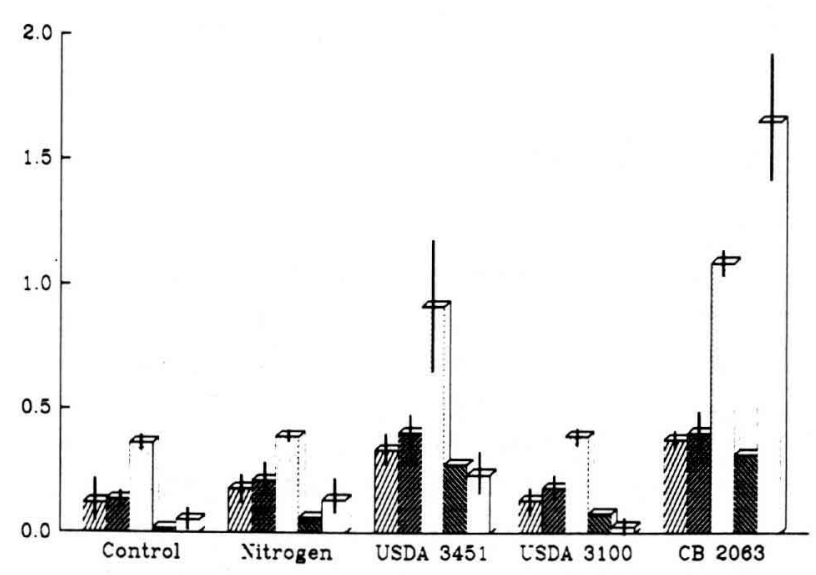

Fig. 5. Effects of treatments (bacterial inoculations or nitrogen fertilization) on dry matter yields ( $\mathrm{g} / \mathrm{plant}$ ) in Psoralea cinerea. ZIIT leaves; roots; immature fruits; $\square$ seeds. The vertical bars are standard deviations of the means.

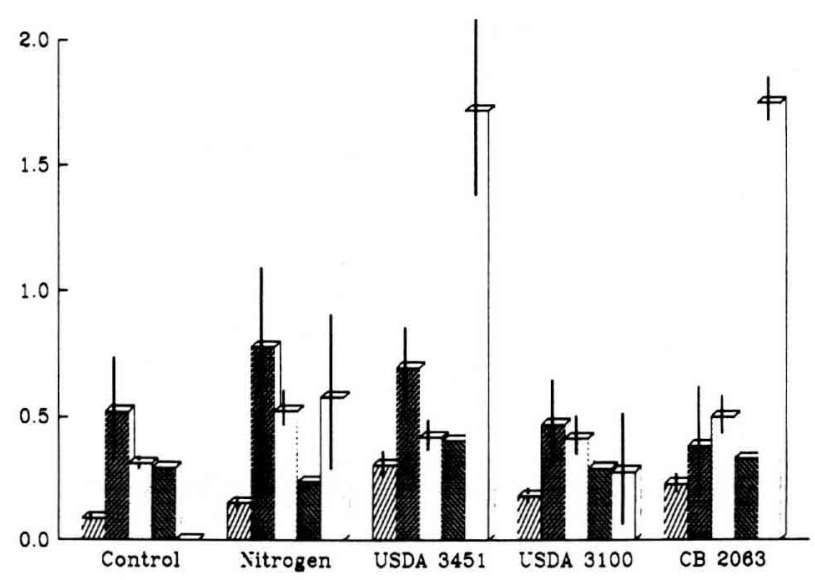

Fig. 6. Effects of treatments (bacterial inoculations or nitrogen fertilization) on dry matter yields ( $\mathrm{g} / \mathrm{plant}$ ) in Psoralea plumo-

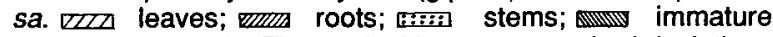
fruits; $\square$ seeds. The vertical bars are standard deviations of the means.

attained a lower height than the other species and exhibited a more bushy habit.

\section{Grain yield}

The seeds were harvested during $64 \mathrm{~d}$ in the case of $P$ cinerea and $72 d$ in the case of $P$ plumosa. The grain yield histograms (fig 5 for $P$ cinerea and fig 6 for $P$ plumosa) confirm the results reported for vegetative growth. The most effective treatments were: strain CB 2 063: 16.5 $\mathrm{g} / 10 P$ cinerea plants; $17.5 \mathrm{~g} / 10 P$ plumosa plants; strain USDA 3 451: $17.2 \mathrm{~g} / 10$ P plumosa plants. This strain did not give high yields with $P$ cinerea.

Nitrogen treatments provided an average production of seeds by $P$ plumosa $(6.3 \mathrm{~g} / 10$ plants) but only a low yield with $P$ cinerea 
(1.3 $\mathrm{g} / 10$ plants). As with vegetative growth, the controls and plants treated with USDA 3100 gave only low seed yields.

\section{Yield parameters}

Tables I and II show yield parameters for $P$ cinerea and $P$ plumosa. For $P$ cinerea, all the parameters vary strongly according to the treatments. But the number of inflorescences per plant is the most sensitive parameter to nitrogen nutrition, followed by number of seeds per inflorescence and, lastly, 1000 seed yield.

For $P$ plumosa, we can notice considerable variations with the number of inflorescence per plant depending on the type of fertilization/inoculation. On the contrary, the number of seeds per inflorescence and 1000 seed weight show little differences from 1 treatment to another. The most important difference between the 2 species is observed with 1000 seed weight parameter.

\section{Presence of root nodules}

The roots systems were observed at the end of the vegetative cycle. Both species inoculated with strain $C B 2063$ showed nodules with a maximum diameter of $3 \mathrm{~mm}$. $P$ plumosa inoculated with strain USDA 3451 formed nodules as large as $7 \mathrm{~mm}$. In all these cases the nodules were distributed uniformly over the root mass. In contrast, the nodules arising on $P$ cinerea inoculated with USDA 3451 had the same appearance as those formed by strain $\mathrm{CB}$ 2063 but were located only at the periphery of the root system, corresponding to young roots. Plants inoculated with strain USDA 3100 , those fertilized with nitrogen and the controls did not form nodules.

\section{DISCUSSION}

\section{Developmental cycle}

The proposed germination method proved to be very effective with a high level of germination $(90 \%)$ within a short time (24-48 h). Two major advantages derive from this: economy in seeds, which is valuable since the seeds come from Australia; the production of synchronous groups of seedlings for growth experiment. The drawback lies, however, in the laborious scarification of the seeds, which makes the method unsuitable for cultivation on a larger scale (greenhouse or field). Chemical scarification tests are being considered for the future.

Table I. Yield parameters for $P$ cinerea growing with different inoculation/fertilization treatments.

\begin{tabular}{c|c|c|c|c}
\hline TREATMENTS & $\begin{array}{c}\text { yield } \\
\text { (g/plant) }\end{array}$ & $\begin{array}{c}\text { inflorescence number } \\
\text { per plant }\end{array}$ & $\begin{array}{c}\text { seed number per } \\
\text { inflorescence }\end{array}$ & $\begin{array}{c}1000 \text { grain } \\
\text { weight }\end{array}$ \\
\hline CB 2063 & 1.65 & 14.3 & 28.1 & 4.11 \\
\hline USDA 3451 & 0.24 & 10.2 & 9.5 & 2.44 \\
\hline USDA 3100 & 0.03 & 1.7 & 8.6 & 1.77 \\
\hline 50 uN/ha & 1.33 & 3.8 & 17.3 & 2.03 \\
\hline CONTROL & 0.05 & 1.7 & 15.2 & 2.05 \\
\hline
\end{tabular}

Table II. Yield parameters for $P$ plumosa growing with different inoculation/fertilization treatments.

\begin{tabular}{c|c|c|c|c}
\hline TREATMENTS & $\begin{array}{c}\text { yield } \\
\text { g/plant })\end{array}$ & $\begin{array}{c}\text { inflorescence number } \\
\text { per plant }\end{array}$ & $\begin{array}{c}\text { seed number per } \\
\text { inflorescence }\end{array}$ & $\begin{array}{c}1000 \text { grain } \\
\text { weight }\end{array}$ \\
\hline CB 2063 & 1.75 & 10.9 & 14.3 & 11.26 \\
\hline USDA 3451 & 1.72 & 10.1 & 15.4 & 11.08 \\
\hline USDA 3100 & 0.28 & 2.8 & 10.0 & 9.89 \\
\hline 50 uN/ha & 0.63 & 4.0 & 15.4 & 10.21 \\
\hline CONTROL & 0 & 0 & ND & ND \\
\hline
\end{tabular}


With regard to the developmental cycle, the conditions chosen here allowed the cycle to be completed with highly satisfactory fruiting and maturation leading to seeds with a 99\% germination capacity. These annual plants thus have a growth period and require growth conditions allowing greenhouse or field cultivation trials under suitable climatic conditions to be seriously considered at a later stage. In our experimentation the temperature summations recorded correspond to mediterranean climate.

\section{Comparison between nitrogen fertilization and inoculation}

The application of a nitrogen dose equivalent to $50 \mathrm{U} / \mathrm{ha}$ had only a mediocre effect on plant growth and yields. Indeed, with $P$ cinerea the vegetative growth parameters (height and total number of leaves) as well as the grain and dry matter yields were low. $P$ plumosa responded no better to the application of nitrogen and only the root and stem yields were high. In effect, better growth in height was observed in plants fertilized with nitrogen, whereas the plants treated with USDA 3451 and CB 2063 ceased their linear growth at the start of the main fruiting period. The nitrogen dose of $50 \mathrm{U} /$ ha seems to have been too small to ensure growth equivalent to that obtained with effective inoculations, which indicates the nitrogen requirements in these plants.

The best growth and yield results with $P$ cinerea were obtained with strain CB 2063. This strain had been isolated from a plant of this species in Australia so that it has good specificity for $P$ cinerea. In parallel, CB 2063 also provided good growth and fruiting of $P$ plumosa so that one and the same strain can therefore establish symbiosis with several species of the genus Psoralea. With $P$ plumosa, strain USDA 3451 gave growth and yield results comparable to those obtained with strain CB 2 063. Since this strain had been isolated from an African legume (Macrotyloma), it can induce nodules in plants not belonging to even the same genus. This strain thus has low specificity.

With regard to the results obtained with the combination of USDA 3451 and $P$ cinerea, the location of the nodules on the young roots at the periphery of the root system has already been emphasized together with their resemblance to the nodules induced by strain CB 2063 . These 2 observations and the late appearance of the inoculation effect with strain USDA 3451 suggest that this treatment replicate had been contaminated with bacteria of strain CB 2063 towards the end of the experiment. Strain USDA 3451 is, in fact, unable to establish symbiosis with $P$ cinerea under our experimental conditions.

Even though it had been isolated from an American species of Psoralea, strain USDA 3100 did not form nodules with either of the 2 studied Psoralea species. The growth and yield results with this treatment applied to the 2 species were comparable in all respects with those obtained in the 2 controls. With regard to the controls, it should also be noted that neither of the 2 plants species exhibited root nodules: the Rhizobium present in the soil in the natural state was unable to establish symbiosis with the Psoralea species.

\section{CONCLUSION}

Despite the small number of strains tested (3) and despite the absence of bibliographic references concerning the growth, fruiting and nodulation of Psoralea, satisfactory growth conditions were determined for the controlled cultivation of the 2 studied species: $P$ cinerea and $P$ plumosa. Good vegetative growth as well as optimal seed yields were obtained with strain CB 2063 associated with $P$ cinerea and with strains CB 2063 and USDA 3451 in the case of $P$ plumosa. A later study should specify the localization and quantity of furocoumarins present in each species in order to determine the respective values of each organ of these plants. This information derived from the present results suggests that both these species can be cultivated on a larger scale (greenhouse or field) in a suitable climate.

\section{ACKNOWLEDGMENTS}

We would like to thank The King's Park Botanical gardens of Perth (Australia) for collecting the Psoralea seeds, and Dr Lane-Brown who made them available to Us; Dr J Brockwell of the Canberra CSIRO for sending strain CB 2 063, and Dr Griffin of the USDA in Beltsville for sending the 2 strains USDA 3451 and USDA 3100.

\section{REFERENCES}

Allen ON, Allen EK (1981) The Leguminosae. A Source Book of Characteristics, Uses, and Nodulation. The University of Wisconsin Press, Madison

Appleman MD, Sears OH (1942) Further evidence of interchangeability among the groups of Rhizobium leguminosarum. Soil Sci Soc Am Proc 7, 263-264 
Baskin JM, Ludlow CJ, Harrist TM, Wolf FT (1967) Psoralen, an inhibitor in the seeds of Psoralea subacaulis (Leguminosae). Phytochemistry 9, $1209-1213$

Beadle NCW (1964) Nitrogen economy in arid and semi-arid plant communities. Part III: The symbiotic nitrogen-fixing organism. Proc Linn Soc NSW 89, 273-286

Bourgaud F, Allard N, Guckert A, Forlot P (1989) Natural sources of furocoumarins (psoralens). In: Psoralens, Past, Present and Future of Photochemoprotection and Other Biological Activities. John Libbey Eurotext, Montrouge, 219-229

Dorbec V (1985) Etude de la fixation symbiotique de l'azote atmosphérique chez deux Légumineuses fouragères perennes Medicago sativa et Psoralea bituminosa. DEA d'Agronomie ENSA de Montpellier Innocenti G, Cappelletti FM, Caporale G (1984) Morphological and chemical characteristics of some
Australian Psoralea species. Int $J$ Drug Res 22, 97-109

Keighery GJ, Dixon IR (1981) Psoralea: The genus in Western Australia. Austr Plants 11, 58-59

Keyser HH, Griffin RF (1987) Beltsville Rhizobium Culture Collection Catalog. USDA, Agricultural Research Service

Torrey JMD, Gray AMD (1969) Flora of North America 1. (Facsimile of the 1838-1843 edition) Hafner Pub Co, NY

Vincent JM (1970) A Manual for the Practical Study of Root Nodule Bacteria. Blackwell Scientific Publications, Oxford

Wood M, Cooper IE, Holding AJ (1963) Method to assess the effects of soil acidity factors on legumeRhizobium symbioses. Soil Biol Biochem 15 , 123-124 